\title{
Trend of Ill-Defined Causes of Death in Egypt (2000-2013) in Comparison to Selected Eastern Mediterranean Countries, and an Intervention Study to Improve The Accuracy of Death Certification in One District in Cairo, Egypt
}

\author{
Eman A. Aly*, Wagida A. Anwar**, Amany M. Abdelhafez **, Sahar A. Dewedar** and \\ Mervat H. Rady** \\ * World Health Organization ** Department of Community, Environmental and \\ Occupational Medicine - Faculty of Medicine Ain Shams University \\ Received: December 2015, accepted: February 2016
}

\section{Abstract}

Introduction: Vital statistics is the core of a country's health information system as it provides estimates of the prevalence and distribution of mortality due to diseases and injuries guiding the health policies. Most developing countries face the challenges of data quality analysis of trends regarding the main causes of death since reliable data are restricted to either areas with a high socioeconomic level or metropolitan cities. Objectives: The objectives of this work were to; Identify the trend of ill-defined death rates in Egypt from 2000 to 2013 and to compare the trends of ill-defined causes of death in Egypt with that of selected countries of the EMR as well as to evaluate the impact of an intervention study on the accuracy of death certification in four health units of one district in Cairo, Egypt. Material and Methods: An ecological, exploratory study of multiple age groups and temporal series from 2000 to 2013, where it is possible to evaluate the temporal evolution of rates of ill-defined causes of death (CoD), through secondary data analysis, which included the total number of ill-defined $\mathrm{CoD}$ that were recorded as due to symptoms, signs, event of undetermined intent and ill-defined conditions, separated by sex and age groups. In parallel, a pilot intervention study to evaluate the impact of on job training on the accuracy of death certification in one district in Cairo, Egypt has been conducted. Results: A total of 3,385,965 ill-defined causes of death out of 6,478,279 deaths were identified between 2000 and 2013, mostly associated with coded symptoms and signs (chapter XVIII and event of undetermined intent) followed by heart failures $8.5-23 \%$ and $10-17 \%$ respectively. A reduction in the overall ill-defined causes of death from 0.41 before intervention to 0.22 after on job training which was conducted using lectures and discussion seminars.

Key words: ill-defined, causes of death CoD, vital statistics, EMR (Eastern Mediterranean region)

\section{Introduction}

$\begin{array}{ll}\text { Civil registration and vital } & \text { However, one of the most challenging } \\ \text { statistics systems (CRVS), when } & \text { products of the CRVS is cause-of-death } \\ \text { functioning properly, are the most } & \text { (CoD) information. The level of } \\ \text { reliable source of continuous data on } & \text { registration of deaths in some countries } \\ \text { fertility, mortality and causes of death. } & \text { could be high but the information on the }\end{array}$


cause of death is either absent or of low quality. The main source of data for the CoD is the Death certificates that filled either by the physicians and or medically trained staff. The death certificate includes information about the main and underlying causes of death (1).

Recent studies have reported many inaccuracies in death certificates worldwide, and their reliability has come under increasing criticism in medical journals and among health officials. While data on the number of deaths in a community or a country is precise and accurate, the identification of the causes of death is often incorrect ${ }^{(2)}$.

Few studies have examined deficiencies in death certification in the developing world; the limited available information suggests that the inaccuracies in the data derived from death certificates are influenced by the certifier, the certificate, the deceased and the cause of death. The death certification is used for medico-legal and epidemiological purposes to evaluate the health status of a population and to allocate health care resources for health service and research. Most physicians complete death certificates as part of their professional duty. However, the information contained in death certificates frequently reveals nonintentional errors ${ }^{(3)}$.

Correct certification of the cause of death needs: the distinction between "cause" and "mechanism" of death, and the distinction between "immediate cause of death" and "underlying cause of death", both of which are included in the death certificate form. Educational interventions have been successful in reducing these errors and improving the accuracy of completion of death certificates by physicians ${ }^{(4)}$ In Egypt, the Cause of Death Registry holds information on deaths and the causes of deaths in a database held in the Health Information System at the Ministry of Health (5). The national health information system relies on a fairly well developed information technology and communication network through which data are collected using international standards at all levels of the system. However, the quality of the data collected is deemed low and there is little use of data in policy-making at all levels of the system ${ }^{(5)}$.

Objectives: The objectives are to identify the trend of ill-defined death rates in Egypt from 2000 to 2013, compare the trends of ill-defined causes of death in Egypt with selected countries of the EMR and to evaluate the impact of intervention study on the accuracy of death certification in four health units of one district in Cairo, Egypt.

\section{Material and Methods}

Phase I: Trend of ill-defined causes of
death in Egypt (2000-2013): The present study is an ecological, exploratory study of multiple age groups and temporal series from 2000 to 2013, where it is possible to evaluate the temporal evolution of rates of ill-defined causes of death through the following: The use of secondary data, which included the total number of ill-defined CoD that were recorded as due to symptoms, signs, event of undetermined intent, separated by sex, age groups which further classified into: Less than one year, 1-4 and 5-19, corresponding to children and adolescents, 20-59 corresponding to adults and 60 years and older.

Calculation of proportionate mortality ratios: Proportionate mortality ratios were calculated for ill-defined causes of death by dividing the number of coded symptoms, signs, event of undetermined intent by the total deaths from all causes 
for each age and sex this was done for the period 2000 to 2013 Calculation of direct standardized rates: Direct standardized rates of ill-defined causes of death were calculated using the available average population for 2000 , 2005 and 2010 as the standard population, Then the standardized rates were calculated by summing the product of multiplication of age and sex-specific death rates of ill-defined causes of death for each year by the number of the standardized population for the same age group and sex.

Comparison to selected Eastern Mediterranean Countries: Egypt cause-specific mortality data as well as the data from other countries of the EMR for the period 2000 to 2013, available on the WHO public website were analysed and categorized, the illdefined causes trends were presented and compared.

\section{Phase II: The Pilot intervention study}

Study design: Intervention study (uncontrolled). Study setting: This study was conducted in four health units in one district in Cairo governorate. Study duration: The total duration of intervention study was 10 months started from February-November 2010; (four months pre-intervention, 2 months for intervention, and 4 months for postintervention phase). Participants: All the death certifiers (twelve participants) at the four health units were included in the study.

Pre-intervention phase: The study started by reviewing the permissible number of death certificates for the four months before the start of the training, using a structured form for identifying major and minor errors in writing the death certificates and calculation of illdefined deaths rates.
Major errors are: Mechanism of death listed without underlying cause, improper sequencing and competing causes. Minor errors are: Use of Abbreviation, Absence of time intervals and Mechanism of death followed by legitimate underlying cause of death

Intervention phase: The intervention was implemented in two-months training based on the international standard guidelines of WHO. Theoretical teaching was conducted using lectures and practical teaching through discussion of different case-scenarios.

Post intervention phase: Death certificates four months post the training, were reviewed and the results compared in terms of the percent of ill-defined causes and frequency of major and minor errors of the studied death forms.

\section{Statistical analysis}

Phase I: The data were extracted from the WHO public website and imported to STATA 13 software. To assess the nature and statistical significance of the trend of ill-defined causes of death, the simple linear regression technique was used, in which the time variable expressed in years, entered the model as the independent variable and the variable proportion of deaths due to ill-defined causes; overall and stratified by sex and age group as the dependent variable. Phase II: Certification of ill-defined causes of death, were compared in the pre and post- intervention death certificates by calculating the Chi-square test using STATA 13 software. A $P$ value $<0.05$ was considered statistically significant.

\section{Results}

A total of $3,385,965$ deaths due to illdefined causes were recorded in Egypt between 2000 and 2013, of which the highest value were during the period 
$2007-2010$ reaches up to 55.8 in 2010 and the lowest value were during 2012 and 2013 it was 45.3 and respectively, meaning that only around half of the deaths that occurred and were registered through the studied time series in Egypt had the underlying cause of death declared. The most reported ill-defined causes of death were the symptoms and Signs (chapter XVIII) and injuries of undetermined intent (Y10-Y34) and heart failure alternately all through the studied period while the least reported one all through the studied period was the pulmonary edema. Figure (1) shows change in the proportion of ill-defined and defined causes of death over years.

Table (1) shows that mortality in males due to ill-defined causes of death was higher than that of females all through the studied period with a male to female ratio ranged from 1.1 to 1.2 . In general the highest proportion of deaths diagnosed as ill-defined was in the age group 20-59 and 60+ yrs, the ranges are $(23-27 \%)$ and (63-66\%) respectively. The proportion of ill-defined causes of death in age group $<1$ year shows a slight increase from $4.8 \%$ in 2000 to $6.6 \%$ in 2005 and then fluctuates between 5 and $6 \%$ until year 2013, the rates are reduced in childhood and adolescent period 1-4 yrs and 5-19 yrs it ranges between $(1.5-1.56 \%)$ and (1.8$3.2 \%$ ) respectively (table 2 )

To assess the nature and statistical significance of the trend of ill-defined causes of death, the simple linear regression technique was used, in which the time variable expressed in years, and Figure (2) shows line trend of deaths due to ill-defined causes registered in Egypt during 2000--2013 where it shows a slight decrease in trend with small oscillations during the studied period and no significance change of the proportion over time.

In figure ( $3 \mathrm{~A} \& \mathrm{~B})$ the trend in males showed a slight increase during the studied period accompanied by decrease in the trend among females figure (3B) $\left(\mathrm{R}^{2}=0.0465\right)$.

There were no marked difference between crude and age standardized mortality rates as shown in figure (4) however the rate of registered ill-defined causes of death increased by $25 \%$ between the years 2005 and 2010 .

The proportional mortality due to illdefined causes trend in Egypt during the study periods (from 2000-2013) was the higher in comparison to the studied EMR countries all through the time series followed by Bahrain then Qatar and in all these countries, the trend was raising. The least trend was for Kuwait and it was decreasing as shown in figure (5). Table (3), shows that there was a reduction in the percentages of all minor errors after the educational intervention but this reduction was statistically highly significant for the use of abbreviations and absence of time intervals only. For the major errors in the death certificate, table (4) shows that there is a highly significant reduction in the percentages of all studied major errors after the intervention and the biggest difference was observed for the competing causes, followed by improper sequencing then the mechanism. The effect of the intervention in reducing the total number of ill-defined causes of death is clear from table (5) as there was a highly significant reduction in this number after the intervention.

\section{Discussion}

This study revealed that the percentage of ill-defined deaths in Egypt during the period (2000-2013) were fluctuating 
between $45.3 \%$ and 56.3 this high percent may be due to lack of physicians training on appropriate writing of death certificates and lack of effective monitoring program. It could be also explained by the change in coding system of deaths from ICD-9 to ICD-10 which started in Egypt in year 2000 with more details about the actual cause of death. In contrast, a study conducted in Thailand during 2009 showed the proportion of ill-defined causes of death dropped from $41 \%$ in 2000 to $31 \%$ in $2009^{(6)}$ and another study in SRI Lanka showed similar reduction (7). In Brazil, 2011 a study conducted by Davi Felix et al showed the proportion of deaths due to ill-defined causes was decreased all through the study period (1979 to 2009), from 45 in the year 1979 to $8 \% 2009^{(8)}$ In the USA and Canada, the percentage of deaths registered as due to ill-defined causes was around 1\% during 2004 (9) and $2.8 \%$ in Chile during $2003^{(10) .}$ This study showed that individuals aged 60 years and higher, had higher ill-defined death rates allover the study period (2000-2013), the highest value was $69 \%$ during the year 2010 and the lowest value was $63 \%$ during the year 2005 . This may be explained by the presence of co-morbidities (diabetes, neoplasias, hypertension, atherosclerosis, arteriosclerosis ...etc) and the influence of aging itself on the clinical manifestation of signs and symptoms, also elderly sometimes refuse to go to receive treatment or visit the healthcare unit which leads to unclear medical history to support identification of the underlying cause of death. In Brazil during 2011, an ecological study by Davi Felix et al supported our findings and stated that the proportion of deaths due to ill-defined causes seen in the elderly (65 years old and over) ${ }^{(8)}$.
The current study showed that males had slight higher rates of ill-defined causes of death than female all over the study period (2000- 2013), the percentages in males ranged between $51 \%$ and $54 \%$, this marked increase was during the year 2011 (the Egyptian revolution period). The male: female ratio was equal to 1.1 during the period from the year 2000-2003 and 1:1.2 during the period from year 2004-- 2013) with no significant relationship between gender and illdefined causes of death, this results agreed with the study conducted in Thailand and showed high percentage of ill-defined causes of death among male, however gender were significantly associated with ill-defined death rate ${ }^{(11)}$. In Brazil during 2011, Davi Félix showed that there is no difference between male and female regarding the proportion of ill-defined causes of death and this results support our study.

The current study showed that there is a significant decrease in the trend among age groups (1-4 years and 5-19 years) over the period (2000-2013), in contrast Davi Félix study stated that there is significant decrease in the trend in the older $(65+$ years $)$ and younger age ( $<1$ year). However in Finland 2014, Ylijoki et al showed that more than $80 \%$ of Danish deaths with ill-defined causes of death were over 70 years of age at the time of death ${ }^{(12)}$.

By comparing the level of ill-defined causes of death in Egypt with the data available from countries of eastern Mediterranean region, those countries are Kuwait- Bahrain- Saudia ArabiaPalestine- Jordan- Morocco- Qatar, we founded that Egypt was showing the highest rates all through the duration of the study (2000 - 2013), followed by Bahrain and Qatar. However the rates in Kuwait and Jordan had the lowest 
proportion of ill-defined causes of death (below 10\% in the period $2004-2013$ ). In Finland 2014, Ylijoki et al conducted a study to analyze the frequencies of illdefined causes of death in Finland and in Denmark and they found that the use of ill-defined causes of death was significantly higher in Denmark than in Finland ${ }^{(12) .}$

Studies examining ill-defined causes of death level in the developing world are rare. Nevertheless, the limited information available suggests that inaccuracies in data derived from death certificates are influenced by various characteristics of the certifier, the certificate, the deceased, and the cause of death ${ }^{(13)}$

The responsibility for non-reporting is shared between the family of a deceased person failing to call a physician and the physician failing to report the cause of death ${ }^{(7)}$, accentuated in countries where there are no laws to enforce the obligations of the certifying physician.

We studied the effect of an on-job training on the frequency of minor and major errors in writing death certificates, our results showed a reduction in the rates of the overall ill-defined cause of death from $41 \%$ before the intervention to $24 \%$ after the intervention , there is also decreased frequency of three types of minor errors by about $20 \%$ for using abbreviation and about $70 \%$ reduction in the absence of time interval, Similar results in a study conducted in Bahrain to assess the impact of an educational intervention on the accuracy of death certification where the percentage of minor errors was reduced by about $30 \%$. The current study also showed that, there was a reduction in the reporting errors of the ill-defined causes of death such as the reporting of essential (primary) hypertension and ill-defined cancer sites with a statistically significant reduction in the reporting $\mathrm{p}$ value $<0.05$.

Another study by Jesus Villar et al from Spain in 2007 (at various Spanish teaching hospitals: family medicine, internal medicine, anesthesiology, general surgery and critical care medicine) suggested that a 90-min seminar had changed the occurrence of at least one major error from 71 to $4 \%$ highlighting the fact that correct certification of the cause of death requires knowing how to differentiate between the two terms "cause" and "mechanism" of death and realize the concepts of "immediate cause of death" and "mechanism of death" (16). Similarly a study by Myers et al from Canada which implemented a 75-min seminar showed that the percent of certificates with at least one major error was dropped from 32.9 to $15.7 \%$. While Lakkiredoly et al from USA revealed that a 45-min workshop enabled $15.5 \%$ of residents to identify correctly the cause of death ${ }^{(17) .}$ Concerning the minor errors in Afzal Azim et al, all pre intervention had no time intervals $(100 \%)$ and use of abbreviation $(89.3 \%)$ after intervention there was a statistically significant decrease to $22.6 \%$ and $29.3 \%$ respectively whereas in Myers et al the probability of finding at least one minor error did not change significantly after the intervention ${ }^{(18) .}$

\section{Conclusion}

The study showed that the ill-defined causes of death reported during the period of 2000-2013 were about 50\% all over the study period with highest value in 2007 (55\%) and lowest value was $45 \%$ in 2012 , over the 13 years of the study period, the highest proportion of ill-defined causes of death associated to a great extent with the coded 
symptoms and signs (chapter XVIII and event of undetermined intend) rates varied from $23 \%$ to $8.5 \%$, followed by causes referred to as heart failure ranges between $10 \%$ and $17 \%$. On job training and practice different case scenarios in appropriate writing of death certificates showed a significant improvement in reducing the ill-defined levels. Death certification completing skills should be revised to interns, medical officers and residents as a part of their continuous medical education and raising awareness on the consequences of a poorly filled out death certification because the errors that have the highest impact on the data quality could be eliminated by the implementation of even the simplest form of educational intervention.

\section{Recommendations}

Raising the awareness on the consequences of a poorly filled out death certification. Death certification should be completed by a physician who is familiar with the patient whenever possible.Resource allocation, for simple educational interventions such as; on-job training or workshops to be conducted regularly. Design training material from real case scenarios of the complex cases they might encounter in their daily work. Monitoring visits using performance evaluation tools to ensure the quality of the death certification

\section{References}

1. United Nations Children's Fund; 2014, Levels and trends in child mortality. Report 2014. Estimates developed by the UN Interagency Group for Child Mortality Estimation. New York: (http://www. childmortality.org/files_v19/download/ unicef- 2013-child-mortality-report- LR10_31_14_195.pdf, accessed 29 July 2015).

The Egyptian Journal of Community Medicine
2. WHO, 2009. Mortality and burden of disease, World HealtH StatiSticS. 2009. 35. Mortality and burden of disease available at http://www.who.int/whosis/whostat/EN_ WHS09_Table1.pdf accessed on March 2016 3. Pritt BS, Hardin NJ, Richmond JA, et al. Death Certification Errors at an Academic Institution. Arch Pathol Lab Med 2005; 129(11): 1476-9.

4. Middleton D, Anderson R, Billingsly T, et al. Death Certification: Issues and Interventions. OJPM 2011; 1(3): 167-70. 11. Maudsley G, Williams L. Death certification - a sad state of affairs. Journal of Public Health Medicine 1994;16:370-1.

5. World Health Organization. WHO methods for life expectancy and healthy life expectancy. Global Health Estimates Technical Paper WHO/HIS/HSI/GHE/2014.5

6. Siejel, J.S., and Olshnsky, S.J., 2010. The demography and epidemiology of human health and aging: aavailable at http://kb.psu.ac.th/psukb/bitstream/2010/ 9168/12/Appendix(2).pdf. Accessed on 159 2015

7. Sibai AM, Nuwayhid I, Beydoun M, Chaaya M. Inadequacies of death certification in Beirut, Lebanon: who is responsible? Bulletin of the World Health Organization 2002;80:555-61.

8. Davi Félix Martins Junior1, Tania Maria Costa2, Maurício Santana Lordelo3, Ridalva Dias Martins Felzemburg4, Trends of mortality from ill-defined causes in the Northeast region of Brazil, 1979-2009

9. Kochanek K, Murphy S, Anderson R, Scott C. Deaths: final data for 2000. Natl Vital Stat Rep. 2004;53(5).

10. Núñez FM, Loreto M, Icaza N, Gloria M. Calidad de las estadísticas de mortalidad en Chile, 1997-2003. Rev. Méd Chile 2006;134:1191-6.

11. Supatip Boonphirom, Chamnein Choonpradub and Apiradee Lim: Trends of mortality rates for ill-defined in 2000-2009, the 3rd CMU Graduate Research Conferencel

12. Ylijoki-Sørensen S1, Sajantila A2, Lalu K3, Bøggild H4, Boldsen JL5, Boel LW6,

$\begin{array}{llll}\text { Vol. } 35 & \text { No. } 2 & \text { April } & 2017\end{array}$


Coding ill-defined and unknown cause of death is 13 times more frequent in Denmark than in Finland. 2014 Nov;244:289-94. doi: 10.1016/j.forsciint.2014.09.016. Epub 2014 Sep 28

13. Jemal, A., Ward, E., Anderson, R. N., \& Thun, M. J. (2003). Influence of Rules From the Tenth Revision of the International Classification of Diseases on U.S. Cancer Mortality Trends. Journal of the National Cancer Institute, 95(22), $1727-1728$. http://doi.org/10.1093/jnci/djg116

14. Kyle J. Foreman, Mohsen Naghavi, Majid Ezzati: Improving the usefulness of US mortality data: New methods for reclassification of underlying cause of death, Department of Epidemiology and Biostatistics, Imperial College London, London, United Kingdom, http://www.pophealthmetrics.com/imedia/12 23194125171835/supp1.docx

15. Afzal Azim, Parikshit Singh, Parmeet Bhatia, Arvind K. Boronia, Mohan Guriar,
Banani Poddar and Ratender K Singh; Impact of an educational intervention on errors in death certification: An observational study from the intensive care unit of a tertiary care teaching hospital. J Anaesthesiol Clin Pharmacol. 2014, 30 (1): 78-81

16. Jesus Villar and Lina Perez-Mendez: Evaluating an educational intervention to improve the accuracy of death certification among trainees from various specialities. BMC Health Services Research 2007, 7:183. 17. Lakkiredoly D R, Basarakodu K R, Vacek JL, Kondur AK, Ramachandruni SK, Esterbrooks DJ, Market RJ, Gowda MS: Improving death certificate completion: a trial of two training interventions. J Gens Intern Med 2007, 22:544-48.

18. Myers KA, Farquhar DRE: Improving the accuracy of death certification. CAMJ 1998, 158:1317-27 
Table (1): Proportion of ill-defined causes of death by sex in Egypt during the period from 2000-2013

\begin{tabular}{|c|c|c|c|c|c|c|c|}
\hline year & $\begin{array}{c}\text { Total } \\
\text { number } \\
\text { of deaths }\end{array}$ & $\begin{array}{c}\text { ill-defined } \\
\text { No. } \\
96\end{array}$ & $\begin{array}{c}\text { Male } \\
\text { No. } \\
\text { 96 }\end{array}$ & $\begin{array}{c}\text { Female } \\
\text { No. } \\
96\end{array}$ & $\begin{array}{l}M / F \\
\text { ratio }\end{array}$ & $\times 2$ & $\begin{array}{c}P \\
\text { value }\end{array}$ \\
\hline 2000 & 382138 & $\begin{array}{c}189309 \\
49.5\end{array}$ & $\begin{array}{c}100,363 \\
53.02\end{array}$ & $\begin{array}{c}88,946 \\
46.98\end{array}$ & 1.1 & 500.1683 & 0.000 \\
\hline 2001 & 406489 & $\begin{array}{c}212320 \\
52.2\end{array}$ & $\begin{array}{c}112,528 \\
53.00\end{array}$ & $\begin{array}{r}99,792 \\
47.00\end{array}$ & 1.1 & 579.0376 & 0.000 \\
\hline 2002 & 419533 & $\begin{array}{c}216731 \\
51.7\end{array}$ & $\begin{array}{c}115,399 \\
53.25\end{array}$ & $\begin{array}{c}101,332 \\
46.75\end{array}$ & 1.1 & 368.3853 & 0.000 \\
\hline 2003 & 437038 & $\begin{array}{c}228267 \\
52.2\end{array}$ & $\begin{array}{c}121,445 \\
53.20\end{array}$ & $\begin{array}{c}106,822 \\
46.80\end{array}$ & 1.1 & 380.5581 & 0.000 \\
\hline 2004 & 433968 & $\begin{array}{c}235200 \\
54.2\end{array}$ & $\begin{array}{c}126,094 \\
53.61\end{array}$ & $\begin{array}{c}109,106 \\
46.39\end{array}$ & 1.2 & 295.8042 & 0.000 \\
\hline 2005 & 431638 & $\begin{array}{c}231267 \\
53.6\end{array}$ & $\begin{array}{c}123,733 \\
53.50\end{array}$ & $\begin{array}{c}107,534 \\
46.50\end{array}$ & 1.2 & 297.3480 & 0.000 \\
\hline 2006 & 442057 & $\begin{array}{c}239553 \\
54.2\end{array}$ & $\begin{array}{c}127,977 \\
53.42 \\
\end{array}$ & $\begin{array}{c}111,576 \\
46.58\end{array}$ & 1.1 & 341.5493 & 0.000 \\
\hline 2007 & 452831 & $\begin{array}{c}250699 \\
55.4\end{array}$ & $\begin{array}{c}134,091 \\
53.49\end{array}$ & $\begin{array}{c}116,608 \\
46.51\end{array}$ & 1.1 & 476.2432 & 0.000 \\
\hline 2008 & 466381 & $\begin{array}{c}259291 \\
55.6\end{array}$ & $\begin{array}{c}138,620 \\
53.46\end{array}$ & $\begin{array}{c}120,671 \\
46.54\end{array}$ & 1.1 & 436.0063 & 0.000 \\
\hline 2009 & 476591 & $\begin{array}{c}265030 \\
55.6\end{array}$ & $\begin{array}{c}142,249 \\
53.67\end{array}$ & $\begin{array}{c}122,781 \\
46.33\end{array}$ & 1.2 & 404.2916 & 0.000 \\
\hline 2010 & 491609 & $\begin{array}{c}327778 \\
57.1\end{array}$ & $\begin{array}{c}168,363 \\
51.36\end{array}$ & $\begin{array}{c}159,415 \\
48.64\end{array}$ & 1.1 & 723.1856 & 0.000 \\
\hline 2011 & 493069 & $\begin{array}{c}246762 \\
50.0\end{array}$ & $\begin{array}{c}134,366 \\
54.45 \\
\end{array}$ & $\begin{array}{c}112,396 \\
45.55\end{array}$ & 1.2 & 284.1194 & 0.000 \\
\hline 2012 & 529233 & $\begin{array}{c}239493 \\
45.3\end{array}$ & $\begin{array}{c}128,122 \\
53.50\end{array}$ & $\begin{array}{c}111,371 \\
46.50\end{array}$ & 1.2 & 373.2262 & 0.000 \\
\hline 2013 & 511183 & $\begin{array}{c}244265 \\
47.8\end{array}$ & $\begin{array}{c}131,834 \\
53.97\end{array}$ & $\begin{array}{c}112,431 \\
46.03\end{array}$ & 1.2 & 498.9405 & 0.000 \\
\hline
\end{tabular}


Table (2): Proportion of ill-defined causes of death by age groups in Egypt during the period from 2000-2013

\begin{tabular}{|c|c|c|c|c|c|c|c|c|c|}
\hline Year & $\begin{array}{l}\text { Total N. } \\
\text { of deaths }\end{array}$ & $\begin{array}{l}\text { Ill-defined } \\
\text { No. }(\%)\end{array}$ & $\begin{array}{l}<1 \mathrm{y} \\
\text { No. (\%) }\end{array}$ & $\begin{array}{l}1-4 \quad y \\
\text { No. }[\%]\end{array}$ & $\begin{array}{l}5-19 \text { y } \\
\text { No. (\%) }\end{array}$ & $\begin{array}{l}20-59 \text { y } \\
\text { No. (\%) }\end{array}$ & $\begin{array}{l}60+y \\
\text { No. }(96)\end{array}$ & $\times 2$ & P value \\
\hline 2000 & 382138 & $\begin{array}{r}189309 \\
{[49.5)} \\
\end{array}$ & $\begin{array}{l}9035 \\
{[4.8]} \\
\end{array}$ & $\begin{array}{r}2840 \\
(1.50) \\
\end{array}$ & $\begin{array}{l}605 B \\
{[3.2]} \\
\end{array}$ & $\begin{array}{r}45048 \\
{[23.8]} \\
\end{array}$ & $\begin{array}{r}126328 \\
(66.7) \\
\end{array}$ & 3.1 & 0.000 \\
\hline 2001 & 406489 & $\begin{array}{r}212320 \\
{[52.2]}\end{array}$ & $\begin{array}{r}11953 \\
{[5.64]}\end{array}$ & $\begin{array}{r}3558 \\
{[1.68]}\end{array}$ & $\begin{array}{r}6318 \\
{[2.96]}\end{array}$ & $\begin{array}{r}51055 \\
{[24.05]}\end{array}$ & $\begin{array}{r}139436 \\
{[65.67]}\end{array}$ & 206 & 0.000 \\
\hline 2002 & 419533 & $\begin{array}{r}216731 \\
{[51.7]} \\
\end{array}$ & $\begin{array}{r}12950 \\
{[5.98]} \\
\end{array}$ & $\begin{array}{r}3623 \\
{[1.67]} \\
\end{array}$ & $\begin{array}{r}6011 \\
{[2.77]} \\
\end{array}$ & $\begin{array}{r}53270 \\
{[24.58]} \\
\end{array}$ & $\begin{array}{l}140877 \\
{[65.00]} \\
\end{array}$ & 1.9 & 0.000 \\
\hline 2003 & 437038 & $\begin{array}{r}228267 \\
(52.2) \\
\end{array}$ & $\begin{array}{r}14245 \\
{[6.25]} \\
\end{array}$ & $\begin{array}{r}3776 \\
(1.65) \\
\end{array}$ & $\begin{array}{r}5914 \\
{[2.59]} \\
\end{array}$ & $\begin{array}{r}55540 \\
(24.33) \\
\end{array}$ & $\begin{array}{r}148792 \\
{[65.18)} \\
\end{array}$ & 1.6 & 0.000 \\
\hline 2004 & 433968 & $\begin{array}{r}235200 \\
{[54.2]}\end{array}$ & $\begin{array}{l}15242 \\
{[6.48]}\end{array}$ & $\begin{array}{r}3913 \\
{[1.66]}\end{array}$ & $\begin{array}{r}5963 \\
{[2.54]}\end{array}$ & $\begin{array}{r}59873 \\
{[25.46]}\end{array}$ & $\begin{array}{r}150209 \\
{[63.86]}\end{array}$ & 1.3 & 0.000 \\
\hline 2005 & 431638 & $\begin{array}{r}231267 \\
{[53.6]} \\
\end{array}$ & $\begin{array}{l}15274 \\
{[6.60]} \\
\end{array}$ & $\begin{array}{r}3743 \\
{[1.62]} \\
\end{array}$ & $\begin{array}{r}6084 \\
{[2.63]} \\
\end{array}$ & $\begin{array}{r}60172 \\
{[26.02]} \\
\end{array}$ & $\begin{array}{r}145994 \\
{[63.13]} \\
\end{array}$ & 9 & 0.000 \\
\hline 2006 & 442057 & $\begin{array}{r}239553 \\
{[54.2]} \\
\end{array}$ & $\begin{array}{r}13989 \\
{[5.83]} \\
\end{array}$ & $\begin{array}{r}3712 \\
{[1.55]} \\
\end{array}$ & $\begin{array}{r}6010 \\
{[2.51]} \\
\end{array}$ & $\begin{array}{r}63430 \\
{[26.49]} \\
\end{array}$ & $\begin{array}{r}152412 \\
{[63.62]} \\
\end{array}$ & 1.1 & 0.000 \\
\hline 2007 & 452831 & $\begin{array}{r}250699 \\
{[55.4]} \\
\end{array}$ & $\begin{array}{r}16184 \\
{[6.46]} \\
\end{array}$ & $\begin{array}{r}3840 \\
{[1.53]} \\
\end{array}$ & $\begin{array}{r}6092 \\
{[2.43]} \\
\end{array}$ & $\begin{array}{r}64484 \\
{[25.72]} \\
\end{array}$ & $\begin{array}{r}160099 \\
{[63.86]} \\
\end{array}$ & 1.1 & 0.000 \\
\hline 2008 & 466381 & $\begin{array}{r}259291 \\
{[55.6]}\end{array}$ & $\begin{array}{l}16233 \\
{[6.26]}\end{array}$ & $\begin{array}{r}4052 \\
{[1.56]}\end{array}$ & $\begin{array}{r}5907 \\
{[2.28]}\end{array}$ & $\begin{array}{r}67442 \\
{[26.01]}\end{array}$ & $\begin{array}{r}165657 \\
{[63.89]}\end{array}$ & 1 & 0.000 \\
\hline 2009 & 476591 & $\begin{array}{r}265030 \\
{[55.6]} \\
\end{array}$ & $\begin{array}{r}16346 \\
{[6.17]} \\
\end{array}$ & $\begin{array}{r}4214 \\
{[1.59]} \\
\end{array}$ & $\begin{array}{r}6028 \\
{[2.27]} \\
\end{array}$ & $\begin{array}{r}70594 \\
{[26.64]} \\
\end{array}$ & $\begin{array}{r}167848 \\
{[63.33]} \\
\end{array}$ & 7.9 & 0.000 \\
\hline 2010 & 491609 & $\begin{array}{r}327778 \\
{[57.1]} \\
\end{array}$ & $\begin{array}{r}17163 \\
{[5.24]} \\
\end{array}$ & $\begin{array}{r}4500 \\
{[1.37]} \\
\end{array}$ & $\begin{array}{r}6513 \\
{[1.99]} \\
\end{array}$ & $\begin{array}{r}7300 B \\
(22.27) \\
\end{array}$ & $\begin{array}{r}226594 \\
{[69.13)} \\
\end{array}$ & 9.9 & 0.000 \\
\hline 2011 & 493069 & $\begin{array}{r}246762 \\
{[50.0]}\end{array}$ & $\begin{array}{l}15149 \\
{[6.13]}\end{array}$ & $\begin{array}{r}3887 \\
{[1.58]}\end{array}$ & $\begin{array}{r}6034 \\
{[2.45]}\end{array}$ & $\begin{array}{r}67078 \\
{[27.18]}\end{array}$ & $\begin{array}{l}154614 \\
{[62.66]}\end{array}$ & 4.8 & 0.000 \\
\hline 2012 & 529233 & $\begin{array}{r}239493 \\
{[45.3]} \\
\end{array}$ & $\begin{array}{r}14441 \\
{[6.03]} \\
\end{array}$ & $\begin{array}{r}2848 \\
{[1.19]} \\
\end{array}$ & $\begin{array}{r}4.469 \\
{[1.87]} \\
\end{array}$ & $\begin{array}{r}62633 \\
{[26.15]} \\
\end{array}$ & $\begin{array}{l}155102 \\
{[64.76]} \\
\end{array}$ & 8.6 & 0.000 \\
\hline 2013 & 511183 & $\begin{array}{r}244265 \\
{[47.8]} \\
\end{array}$ & $\begin{array}{r}13867 \\
{[5.68]}\end{array}$ & $\begin{array}{r}3050 \\
{[1.25]}\end{array}$ & $\begin{array}{r}4767 \\
{[1.95]} \\
\end{array}$ & $\begin{array}{r}64571 \\
{[26.43]}\end{array}$ & $\begin{array}{r}158010 \\
{[64.69]}\end{array}$ & 9.6 & 0.000 \\
\hline
\end{tabular}


Table (3): The frequency of minor errors in the studied death certificates before and four months after the educational intervention at studied health center

\begin{tabular}{|l|r|r|r|r|}
\hline Minor errors & $\begin{array}{c}\text { Pre (N= 1169) } \\
\text { Studied 10\%= 116 } \\
\mathbf{N}(\%)\end{array}$ & $\begin{array}{c}\text { Post (N= 1112) } \\
\text { Studied 10 \%= 112 } \\
\mathbf{N ~ ( \% ) ~}\end{array}$ & $\mathbf{X}^{\mathbf{2}}$ & $\boldsymbol{P}$ \\
\hline Use of abbreviations & $56(48.3)$ & $23(20.5)$ & 19.37 & $<0.001$ \\
\hline $\begin{array}{l}\text { Error in recording of } \\
\text { inappropriate information }\end{array}$ & $31(26.7)$ & $26(23.2)$ & 0.374 & 0.541 \\
\hline Absence of time intervals & $116(100.0)$ & $25(22.3)$ & 145.7 & $<0.001$ \\
\hline
\end{tabular}

Table (4): Frequency of major errors in the studied death certificates before and 4 months after the educational intervention at studied health center

\begin{tabular}{|l|r|r|r|c|}
\hline Major errors & $\begin{array}{c}\text { Pre (N=116) } \\
\mathbf{N}(\boldsymbol{\%})\end{array}$ & $\begin{array}{c}\text { Post } \mathbf{( N = 1 1 2 )} \\
\mathbf{N}(\boldsymbol{\%})\end{array}$ & $\mathbf{X}^{\mathbf{2}}$ & $\mathbf{P}$ \\
\hline Mechanism only & $54(46.6)$ & $13(11.6)$ & 33.53 & $<0.001$ \\
\hline Improper sequencing & $76(65.5)$ & $26(23.2)$ & 41.24 & $<0.001$ \\
\hline Competing causes & $75(64.7)$ & $12(10.7)$ & 70.26 & $<0.001$ \\
\hline
\end{tabular}

Table (5): Frequency of the total ill-defined causes of death before and 4 months after implementing the educational intervention at studied health center

\begin{tabular}{|l|r|r|r|r|}
\hline Total causes of death & $\begin{array}{c}\text { Pre -intervention } \\
\text { N (\%) }\end{array}$ & $\begin{array}{c}\text { Post- intervention } \\
\mathbf{N}(\%)\end{array}$ & $\mathbf{X}^{\mathbf{2}}$ & \multicolumn{1}{|c|}{$\mathbf{P}$} \\
\hline Defined & $689(58.9)$ & $852(76.6)$ & & \\
\cline { 1 - 3 } Ill-defined & $480(41.1)$ & $260(22.4)$ & 81.27 & $<0.001$ \\
\hline Total & $1169(100.0)$ & $1112(100.0)$ & & \\
\hline
\end{tabular}




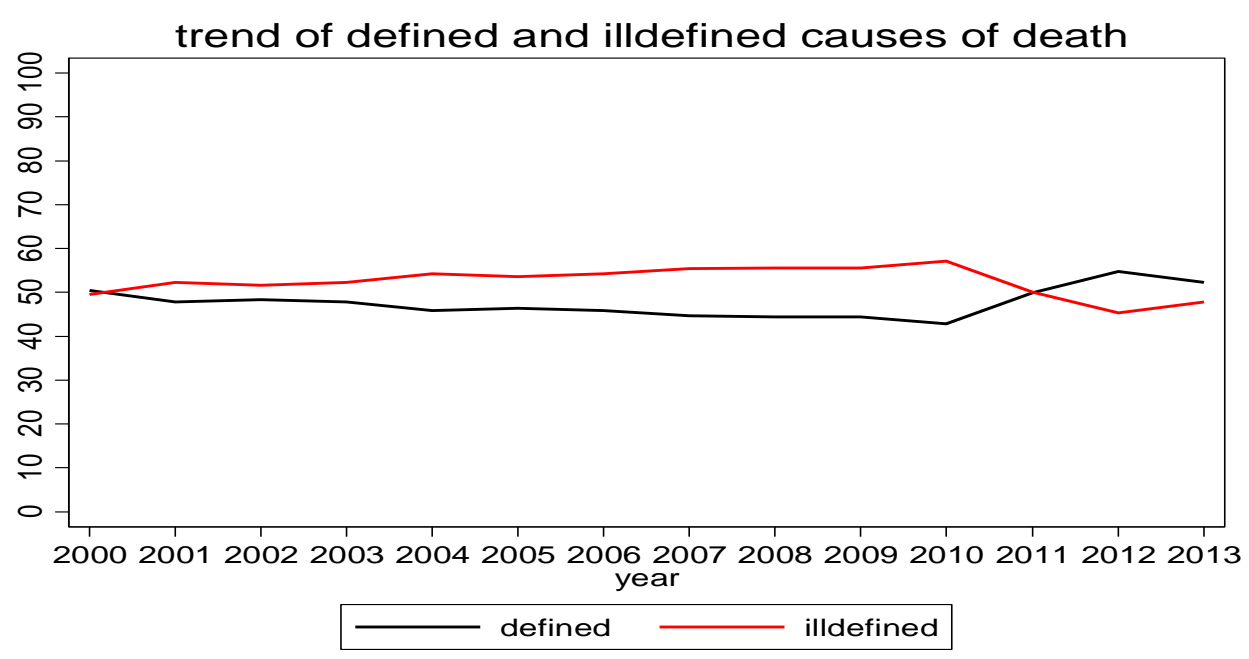

Figure (1): Change in the proportion of ill-defined and defined causes of death over years

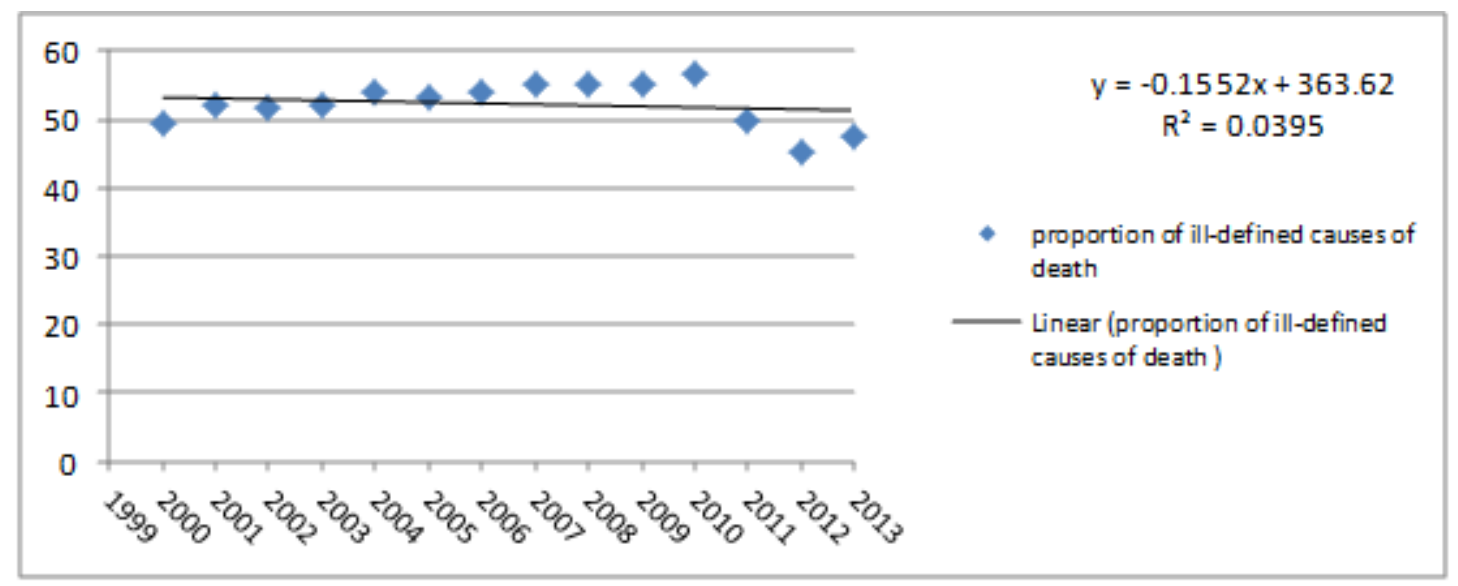

Figure (2): Trend line of proportion of ill-defined causes of death during the period 20002013 


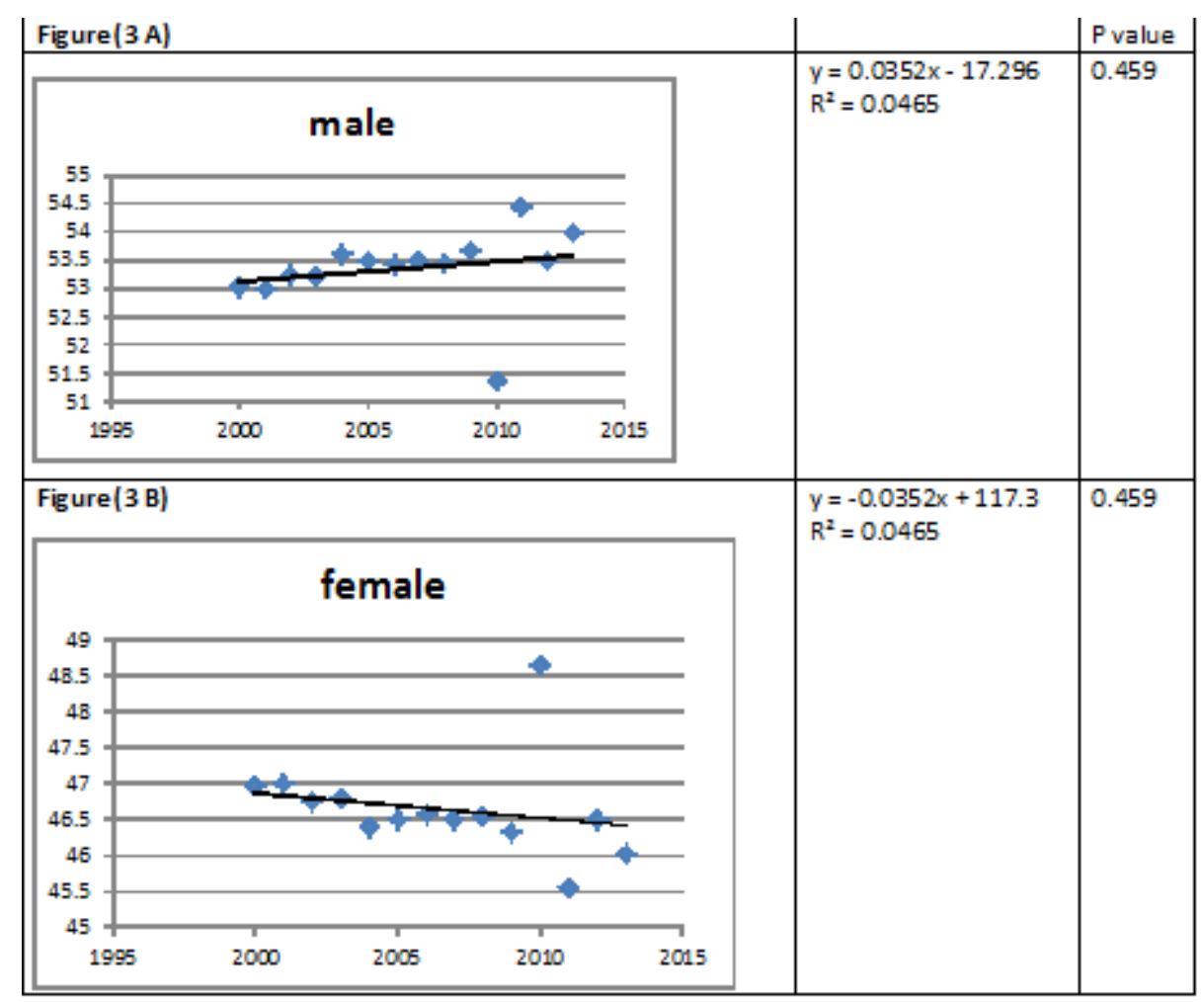

Figure ( $3 \mathrm{A \&}$ B): Trend line of ill-defined causes of death among male and female during the period 2000-2013

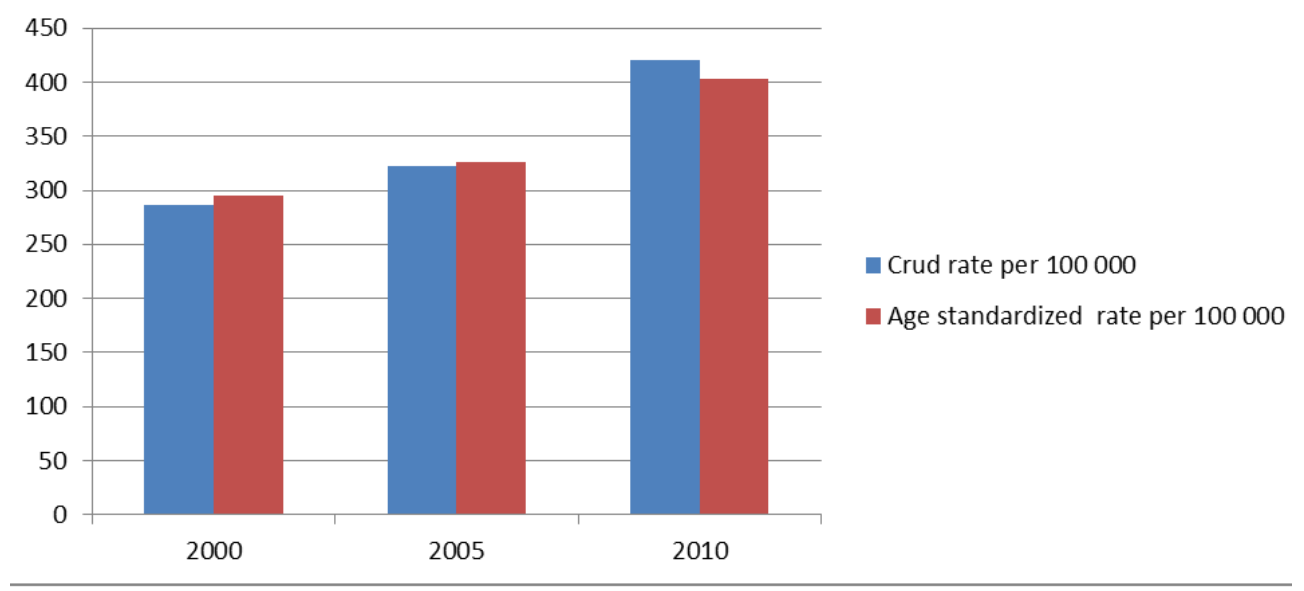

Figure (4): Age and sex Standardized mortality rate for ill-defined causes of death

No. 2 


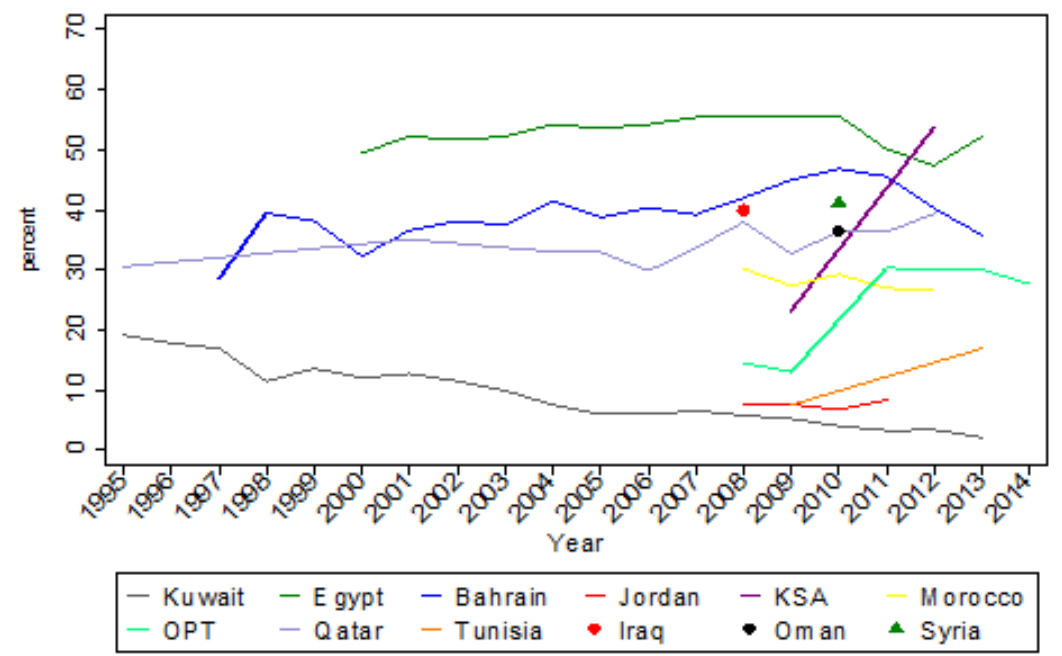

Figure (5): The trend of ill-defined causes of death in Egypt and EM countries 